\title{
Insulin receptors in the gastrointestinal tract of the rat fetus: quantitative autoradiographic studies
}

\author{
F. Sodoyez-Goffaux ${ }^{1}$, J.C.Sodoyez ${ }^{2}$ and C.J.De $\operatorname{Vos}^{1}$ \\ Departments of ${ }^{1}$ Paediatrics and ${ }^{2}$ Internal Medicine, University of Liège, Liège, Belgium
}

\begin{abstract}
Summary. Purified carrier-free ${ }^{125}$ I-insulin was injected into the vitelline vein of rat fetuses in utero after 17, 19 or 21 days of a 22-day gestation. Three minutes later, the weight and radioactivity of various organs and the remaining carcass were measured. A radioactivity concentration index was calculated by dividing the specific activity of each organ by that of the whole feto-placental unit. In each of the three age groups studied, the gastrointestinal tract radioactivity concentration indices were $1.7,2$ and 1.9 respectively, indicating that the gastrointestinal tract concentrated the labelled hormone. Three, 9 and $15 \mathrm{~min}$ after ${ }^{125} \mathrm{I}$-insulin injection, the gastrointestinal tract was removed, homogenized and chromatographed on a G-50 fine Sephadex column. At $3 \mathrm{~min}, 91.4 \%$ of gastrointestinal tract radioactivity co-eluted with a standard of ${ }^{125} \mathrm{I}$-insulin. At the later time intervals studied, the percentage of ${ }^{125} \mathrm{I}$-insu-
\end{abstract}

lin decreased while that of low molecular weight degradation products increased. Quantitative autoradiographic study of the fetal gastrointestinal tract indicated that epithelial cells bound ${ }^{125} \mathrm{I}$-insulin and that this binding was inhibited by coinjection of large amounts of unlabelled insulin. ${ }^{125}$ I-insulin binding was highest in the proximal small bowel and lowest in the colon. Insulin binding did not appear to depend upon degree of cell maturation or cell type. These results indicate that the epithelium of the gastrointestinal tract is characterized by the presence of numerous insulin receptors and is a potentially important insulin target.

Key words: Fetal gastrointestinal epithelium, insulin receptors, rat fetus, quantitative autoradiograph.
The physiological role of insulin during late fetal life is still a debatable matter, largely because good models of insulin lack or of insulin excess are scarce. Lack of insulin during late fetal life is probably best examplified by transient neonatal diabetes in man. In these patients, portal plasma insulin concentration is below assay sensitivity, whereas plasma glucagon concentration is easily measurable. Subcutaneous fat is markedly reduced and the overall appearance of the neonate is that of a dysmature, with near-normal body length but decreased body weight [1, 2]. In contrast, during late gestation, continuous insulin infusion in the rhesus monkey fetus in utero induces an increase of body weight, and in particular of placenta, liver, heart and spleen weights; body length and lung, brain and kidney weights remain unchanged [3]. In both models, fetal blood glucose concentrations remain at near-normal levels, as this substrate is in equilibrium with the relatively much larger maternal pool. Both models suggest that insulin is a selective growth factor for some organs in which abundant insulin receptors have been found [4-8]. Previous studies directed at determining the distribution of insu- lin in vivo in the near-term rat fetus (length of gestation: 22 days) demonstrated an insulin-extracting and -concentrating activity in the liver, heart and kidneys $[5,9]$. The liver bound the largest fraction of injected ${ }^{125}$ I-insulin and had the highest specific activity. Tracer binding to the liver was saturable, indicating a receptor mediated process [5]. In contrast, in fetuses in which the insulin receptor compartment had been saturated by an excess of unlabelled insulin, kidney uptake of ${ }^{125} \mathrm{I}$-insulin did increase, indicating that, even though true insulin receptors exist in the kidneys, the predominant mechanism of tracer uptake is non-receptor mediated and comprises mainly glomerular filtration and absorption by the proximal tubular cells [9]. As these near-term rat fetuses approached the time of delivery, the liver and kidneys bound relatively more insulin. Yet, even at 21 days of gestation, approximately $50 \%$ of the injected tracer was unaccounted for. Therefore, autoradiographic studies of frozen dried sections of whole near-term fetuses were performed to determine which organs, in addition to the liver and kidneys, bound ${ }^{125} \mathrm{I}$-insulin. These studies revealed that significant amounts of radioactivity were 
Table 1. Radioactivity concentration index of gastrointestinal tract of 17-, 19- or 21-day post coitum fetuses

\begin{tabular}{lccc}
\hline & $\begin{array}{l}\text { 17-day fetuses } \\
(n=9)\end{array}$ & $\begin{array}{l}\text { 19-day fetuses } \\
(n=10)\end{array}$ & $\begin{array}{l}21 \text {-day fetuses } \\
(n=10)\end{array}$ \\
\hline Body weight $(\mathrm{mg})$ & $1240 \pm 141$ & $3039 \pm 173$ & $6418 \pm 515$ \\
Gastrointestinal tract weight $(\mathrm{mg})$ & $21 \pm 3$ & $105 \pm 10$ & $344 \pm 27$ \\
Gastrointestinal tract radioactivity (\% of total injected) & $3.0 \pm 0.6$ & $6.9 \pm 0.9$ & $9.8 \pm 2.0$ \\
Gastrointestinal tract radioactivity concentration index, b & $1.74 \pm 0.36$ & $2.01 \pm 0.30$ & $1.90 \pm 0.48$ \\
Carcass radioactivity concentration index & $0.72 \pm 0.10$ & $0.45 \pm 0.07$ & $0.50 \pm 0.06$ \\
\hline
\end{tabular}

Results expressed as mean \pm SD. a Equality of gastrointestinal tract radioactivity concentration index group means was tested by one-way analysis of variance $\left(\mathrm{F}=1.18<\mathrm{F}_{0.05}=3.37\right)$. ${ }^{\mathrm{b}}$ Statistically different from corresponding carcass radioactivity concentration index $(p<0.001 ;$ unpaired t-test)

bound by the gastrointestinal tract (F.Sodoyez-Goffaux, unpublished data). Furthermore, the quantitative importance of the gastrointestinal tract was established by the observation that, near-term, up to $10 \%$ of the radioactivity of an injected tracer dose of ${ }^{125} \mathrm{I}$-insulin was recovered in that organ [5]. These observations prompted us to study in more detail the mechanism of uptake of insulin by the fetal digestive tract and to determine the influence of such factors as growth, differentiation of the epithelium and changes of plasma insulin concentration.

\section{Methods}

\section{Animals}

Female albino rats $(250 \mathrm{~g}$, aged $10-12$ weeks) were caged overnight with a male rat. The gestational age of the fetuses was known within $12 \mathrm{~h}$. Pregnant rats were anaesthetized with nembutal $(15 \mathrm{mg}$, intraperitoneally) at 17,19 or 21 days post-coitum and the distal portion of a uterine horn was exposed. Intravenous insulin injections into nearterm fetuses were performed into the vitelline vein using a $10-\mu l$ microsyringe (Hamilton, Reno, Nevada, USA) mounted with a $26 \mathrm{~S}$ gauge needle, taking care not to perforate the fetal membranes.

\section{Labelled and unlabelled insulin}

Monocomponent bovine insulin was monoiodinated with ${ }^{125} \mathrm{I}$ using the lactoperoxidase method and purified as described previously [10]. Specific activity was $200-300 \mu \mathrm{Ci} / \mu \mathrm{g}$. Before use, the labelled hormone was rechromatographed on a G-50 fine Sephadex column. The unlabelled hormone for competitive studies was pork monocomponent insulin (Actrapid, kindly provided by Novo, Copenhagen, Denmark).

\section{Analysis of gastrointestinal tract radioactivity}

Seventeen, 19- or 21-day-post-coitum fetuses (9-10 in each group) were injected with ${ }^{125} \mathrm{I}$-insulin $(60,000 \mathrm{cpm} / \mathrm{g}$ body weight). Three min later, the whole gastrointestinal tract, including the digestive tube from the stomach to the colon and the pancreas, was dissected and weighed, its radioactivity was measured and the specific activity calculated. After complete thoracic and abdominal evisceration, the specific activity of the remaining carcass was measured similarly. The results were normalized using radioactivity concentration indices ( $\mathrm{RCl}$ ), i.e. the ratio of organ or carcass specific activity to total body specific activity. In a group of 21-day-post-coitum fetuses, the digestive tract was divided into four segments (stomach, proximal and dis-
Table 2. Radioactivity concentration index at various levels of the gastrointestinal tract of 21-day-post-coitum fetuses

\begin{tabular}{|c|c|c|c|c|}
\hline & Stomach & $\begin{array}{l}\text { Proximal } \\
\text { small bowel }\end{array}$ & $\begin{array}{l}\text { Distal } \\
\text { small bowel }\end{array}$ & Colon \\
\hline Weight (mg) & $44 \pm 8$ & $87 \pm 12$ & $60 \pm 9$ & $15 \pm 3$ \\
\hline $\begin{array}{l}\text { Organ radioactiv- } \\
\text { ity ( } \% \text { of total } \\
\text { injected) }\end{array}$ & $1.26 \pm 0.15$ & $3.13 \pm 0.43$ & $1.84 \pm 0.39$ & $0.33 \pm 0.10$ \\
\hline $\begin{array}{l}\text { Organ radioactiv- } \\
\text { ity concentra- } \\
\text { tion index }\end{array}$ & $1.58 \pm 0.26$ & $1.96 \pm 0.27$ & $1.65 \pm 0.22$ & $1.16 \pm 0.16$ \\
\hline
\end{tabular}

Results expressed as mean $\pm \mathrm{SD}, n=22 .{ }^{\text {a }}$ Radioactivity concentration index group means were found unequal by one-way analysis of variance $\left(\mathrm{F}=44.43>\mathrm{F}_{0.01}=4.04\right)$. Contrasts: 1 . proximal small bowel radioactivity concentration index was higher than stomach and distal small bowel $\left(F=32.35>F_{0.01}=6.96\right) ; 2$. colon was lower than stomach and distal small bowel $\left(F=113.41>F_{0.01}=6.96\right)$

tal small bowel and colon) and for each one, the corresponding RCI was calculated.

To determine whether gut-bound radioactivity was insulin or degradation products, 21-day-post-coitum fetuses (three in each group) were injected intravenously with $0.3-0.5 \mu \mathrm{Ci} / \mathrm{g}{ }^{125} \mathrm{I}$-insulin. The small and large bowels were removed at 3,9 and $15 \mathrm{~min}$ and immediately homogenized in $5 \mathrm{ml}$ ice-cold acetic acid $(1 \mathrm{~mol} / \mathrm{l}) / \mathrm{urea}(7 \mathrm{~mol} / \mathrm{l})$, using a homogenizer (Polytron PT 10 Kinematica, Kriens/Luzern, Switzerland). The homogenates were centrifuged at $2500 \mathrm{~g}$ for $30 \mathrm{~min}$ and the precipitates discarded. Over $90 \%$ of the initial radioactivity was recovered in each supernatant, $1 \mathrm{ml}$ of which was chromatographed on a $60 \times 1.2 \mathrm{~cm}$ G-50 fine Sephadex column, equilibrated and developed with $3 \mathrm{ml} / \mathrm{h}$ of the same acetic acid/urea solution. In each set of experiments, the bowel of a control fetus was transferred to $5 \mathrm{ml}$ homogenization medium containing $\sim 500,000 \mathrm{cpm}{ }^{125} \mathrm{I}$-insulin. This sample, processed exactly as the experimental ones, served as control of ${ }^{125} \mathrm{I}$-insulin degradation during the homogenization, storage and chromatographic procedures.

\section{Quantitative autoradiographic studies}

Seventeen-, 19- or 21-day-post-coitum fetuses were injected intravenously with $0.5-1 \mu \mathrm{Ci} / \mathrm{g}{ }^{125} \mathrm{I}$-insulin alone or mixed with unlabelled insulin $(100 \mathrm{mU})$. At 3 and $9 \mathrm{~min}$, the stomach, jejunum, ileum and colon were dissected, fixed in $4 \%$ glutaraldehyde in $0.15 \mathrm{~mol} / 1$ phosphate buffer ( $\mathrm{pH} 7.4$ ), post-fixed in $1 \%$ osmium tetroxide, embedded in epon and cut into sections $(1 \mu \mathrm{m})$ using a M-T 1 ultramicrotome (Porter Bloom, Newtown, Connecticut, USA). The sections were coated with L4 size A emulsion (Ilford, Basildon, Essex, UK) allowed to stand for 4 weeks at $4^{\circ} \mathrm{C}$, then revealed in $4 \%$ Rodinal (Agfa-Gevaert, Leverkusen, FRG), fixed in $250 \mathrm{~g} / 1$ sodium thiosulphate and stained 


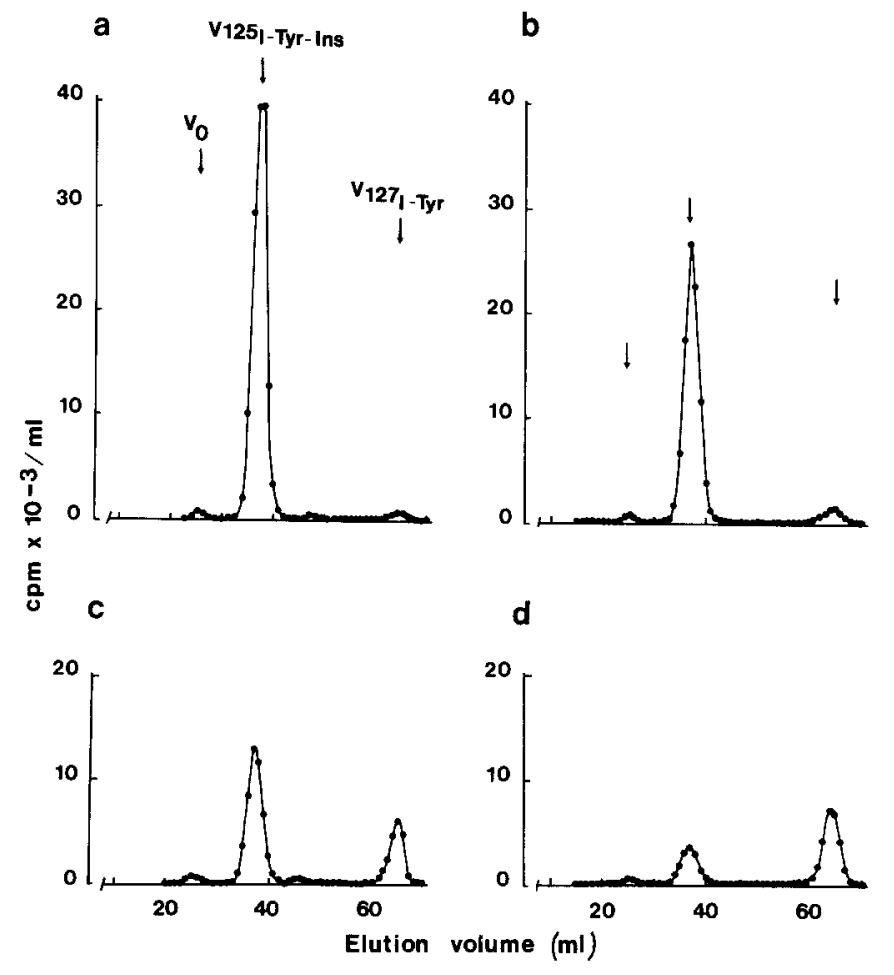

Fig. 1. Elution profile of radioactivity after G-50 Sephadex chromatography. ${ }^{125} \mathrm{I}$-insulin was a added before gastrointestinal tract homogenization or b, $\mathbf{c}, \mathbf{d}$ intravenously injected $3,9,15$ min respectively before gastrointestinal tract removal. Radioactivity eluting in the same volume as a ${ }^{125} \mathrm{I}$-insulin standard was considered to be ${ }^{125} \mathrm{I}$-insulin. Small alterations of the molecule, such as hydrolytic cleavage of a peptide bond, cannot be excluded

Table 3. Analysis of small and large bowel radioactivity following an intravenous bolus injection of ${ }^{125} \mathrm{I}$-insulin into 21 -day-post-coitum fetuses

\begin{tabular}{llll}
\hline & \multicolumn{3}{l}{$\begin{array}{l}\text { Time after intravenous } \\
\text { injection }\end{array}$} \\
\cline { 2 - 4 } & $3 \mathrm{~min}$ & $9 \mathrm{~min}$ & $15 \mathrm{~min}$ \\
\hline Organ radioactivity $\left(\mathrm{cpm} \times 10^{-3}\right)$ & 602 & 486 & 316 \\
Percentage of organ radioactivity identi- & & & \\
fied as: & 91.4 & 61.5 & 33.5 \\
${ }^{125} \mathrm{I}$-insulin & 5.4 & 30.0 & 61.7 \\
${ }^{125}$ I-tyrosine $+{ }^{125}$ I-iodide & & & \\
Organ radioactivity $\left(\mathrm{cpm} \times 10^{-3}\right)$ identi- \\
fied as:
\end{tabular}

with $1 \%$ toluidine blue. For each organ, six photomicrographs (magnification $\times 320$ on a $24 \times 36 \mathrm{~mm}$ negative) were taken under immersion using a Photomicroscope III (Carl Zeiss, Oberkochen, FRG). On each photomicrograph, all the silver grains were counted and assigned to epithelium, lumen or the rest of the intestinal wall. The corresponding areas were measured using an image analysis system (Leitz, Wetzlar, FRG) and the surface densities of grains were calculated. A total of 168 pictures obtained from 16 fetuses were examined and on each picture $500-1000$ grains were counted. Since in all instances the surface density of grains in the epithelium was significantly higher in the presence of ${ }^{125} \mathrm{I}$-insulin alone than after saturation of the receptor compartment by an excess of unlabelled insulin, we report only the quantitative data obtained at $3 \mathrm{~min}$.

\section{Statistical analysis}

All results are expressed as mean $\pm S D$. Statistical analyses were performed using the Student's t-test on unpaired data. When more than two experimental groups were compared, analysis of variance was performed and contrasts were determined.

\section{Results}

\section{Relative concentration of radioactivity in the gastrointestinal tract}

Gastrointestinal tract growth was faster than whole body growth during the last 5 days of intra-uterine life (Table 1). The percentage of radioactivity recovered in the gastrointestinal tract $3 \mathrm{~min}$ after ${ }^{125} \mathrm{I}$-insulin injection rose from 3\% in 17-day-post-coitum fetuses to $9.8 \%$ in 21-day-post-coitum fetuses. To determine whether the apparent increase in gastrointestinal tract extraction of radioactivity was due to organ growth or to maturation of insulin-concentrating tissues, results were normalized for weight, using radioactivity concentration indices. By definition, an RCI above 1 indicates that the corresponding organ binds relatively more insulin per unit weight. The gastrointestinal tract $\mathrm{RCI}$ respectively were 1.74, 2.01 and 1.90 in 17-, 19- and 21-day post-coitum fetuses and analysis of variance showed that the means of the three groups were not statistically different (Table 1). All segments of the gastrointestinal tract concentrated ${ }^{125}$ I-insulin albeit with different degrees. Indeed, in 21-day post-coitum fetuses, the RCI was highest in the proximal small bowel, intermediate in the stomach and distal small bowel and lowest in the colon (Table 2).

\section{Radiochemical analysis of gastrointestinal tract radioactivity}

The G-50 Sephadex column elution profile of radioactivity extracted from the gastrointestinal tract at 3,9 and $15 \mathrm{~min}$ in 21-day-post-coitum fetuses is shown in Figure 1 . No ${ }^{125}$ I-insulin degradation occurred during the homogenization, storage or chromatographic procedures (Fig. 1 a). After 3 min, over $90 \%$ of the gastrointestinal tract extractable radioactivity was eluted in the same volume as an ${ }^{125} \mathrm{I}$-insulin standard (Fig. 1b). As the time after ${ }^{125}$ I-insulin injection increased, less radioactivity appeared in the ${ }^{125} \mathrm{I}$-insulin elution volume and an increasing percentage was recovered in the total gel bed volume (Fig. 1c and d). As previously noted in liver [5] and lung [11] extracts of fetal tissues, no degradation products of intermediate molecular weight were found.

At $3 \mathrm{~min}$, gastrointestinal tract radioactivity was 91\% ${ }^{125} \mathrm{I}$-insulin (Table 3). Between 3 and $15 \mathrm{~min}$, total gastrointestinal tract radioactivity decreased and its radiochemical composition changed so that the total amount of extractable insulin decreased fivefold and that of small molecular weight degradation products increased sixfold. 

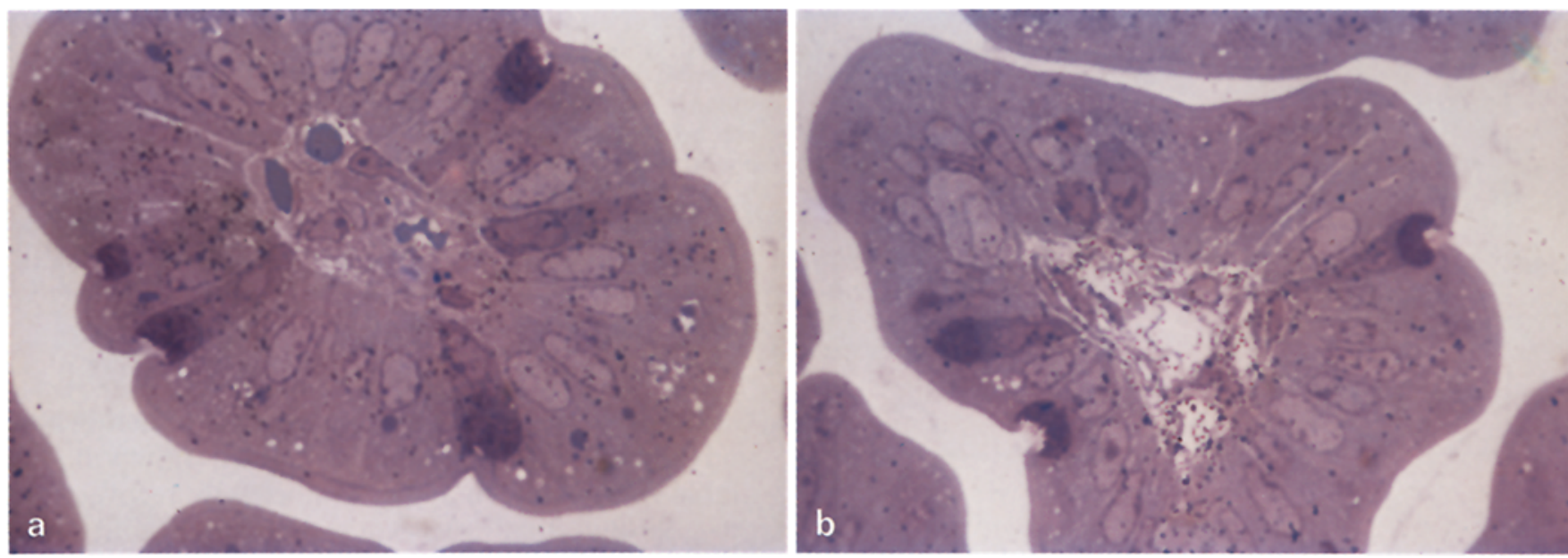

Fig. 2a and b. Autoradiographs of cross-section of jejunal villi taken 3 min after intravenous injection of ${ }^{125}$ I-insulin a alone or $\mathbf{b}$ mixed with an excess of unlabelled insulin $(\times 320$ on the $24 \times 36$ negative)

Table 4. Quantitative analysis of autoradiographs of gastrointestinal tract of 17-, 19- and 21-day-post-coitum fetuses

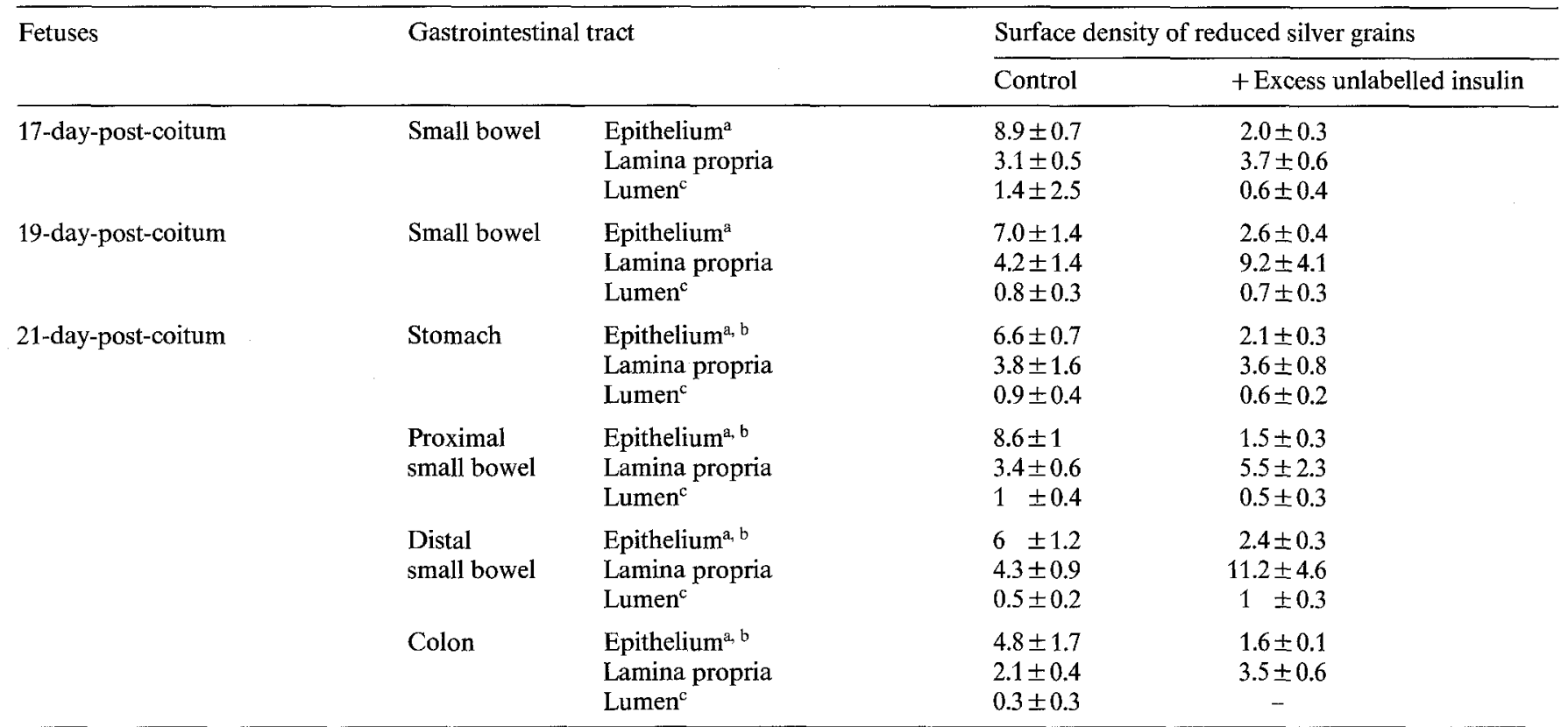

Results expressed as mean \pm SD. ${ }^{\text {a }}$ Epithelium surface density means were found unequal by one way analysis of variance $\left(F=63.6>F_{0.01}=2.56\right)$. Contrast: control epithelia were higher than epithelia + excess unlabelled insulin $\mathrm{F}=595>\mathrm{F}_{0.01}=7.08$. ${ }^{\mathrm{b}}$ 21-day post-coitum epithelium surface density means were found unequal by one way analysis of variance $\left(F=10.3>F_{0.01}=4.94\right)$. Contrasts: 1. proximal small bowel was higher than stomach and distal small bowel $\left(F=14.49>F_{0.01}=8.10\right)$; 2. colon was lower than stomach and distal small bowel $\left(F=5.71>F_{0.05}=4.35\right)$. ${ }^{c}$ Equality of lumen surface density means were tested by one-way analysis of variance $\left(\mathrm{F}=1.148<\mathrm{F}_{0.05}=2.01\right)$

\section{Autoradiographic studies}

Figure 2 illustrates autoradiographs of jejunum villi of 21-day-post-coitum fetuses taken 3 min after injection of ${ }^{125}$ I-insulin alone (Fig. 2 a) or mixed with an excess of unlabelled insulin (Fig.2b). In Figure 2a, silver grains are clearly associated with both types of epithelial cells, the columnar absorptive cells and the goblet cells. Examination of 84 autoradiographs suggests that grains are more numerous at the basal than at the apical aspect of the epithelium and that very few grains are visible in the striated border. Very little radioactivity is present in the intestinal lumen and lamina propria. In contrast, in the presence of an excess of insulin the pattern is reversed (Fig. 2b): few grains are associated with the epithelial cells and most remain in the capillaries or in the loose connective tissue of the lamina propria.

Quantitative analysis of the surface density of grains was performed on the small bowel of the 17- and 19-day post-coitum fetuses and, in the older fetuses, on each segment of the gastrointestinal tract, i. e. stomach, proximal and distal small bowel and colon. In all samples examined after ${ }^{125}$ I-insulin alone, the surface density of grains was highest in the epithelial cells and lowest in 
the lumen (Table 4). After co-injection of $100 \mathrm{mU}$ of insulin, the surface density of grains was highest in the lamina propria and lowest in the lumen. Analysis of variance on all groups of lumen shows that none is different from the others. Thus surface density of grains on the lumen is not only low but also independent of the studied conditions; it most likely represents background activity. In the presence of excess unlabelled insulin, epithelium-associated grains significantly decreased indicating that unlabelled insulin competed with ${ }^{125} \mathrm{I}$-insulin for a finite number of binding sites. Comparison of the various segments of the gastrointestinal tract of 21-day post-coitum fetuses shows that the surface density of epithelial silver grains was in the following order: proximal small bowel $>$ stomach and distal small bowel > colon.

\section{Discussion}

These results show evidence that the epithelium of the gastrointestinal tract is equipped with insulin receptors. An RCI above one is indicative of the presence of insulin receptors, although not proof of it. The highest RCI are found in the liver and kidneys. In the former, ${ }^{125}$ I-insulin binding is due to the presence of specific receptors, whereas in the latter, ${ }^{125}$ I-insulin is predominantly taken up by a non-receptor mediated mechanism consisting of glomerular filtration followed by tubular reabsorption [5].

The presence of insulin receptors in the gastrointestinal tract is, however, very likely in view of the chromatographically identified ${ }^{125} \mathrm{I}$-insulin and the additional autoradiographic demonstration that ${ }^{125}$ I-insulin binding was saturable by co-injection of an excess of unlabelled insulin. Cross-reaction of ${ }^{125} \mathrm{I}$-insulin with the receptor of a structurally related peptide such as insulin-like growth factor cannot, however, be excluded, although it is unlikely in view of the low nanomolar concentration of ${ }^{125} \mathrm{I}$-insulin in the plasma.

Similar findings were reported recently in adult rats. Bergeron et al. presented autoradiographic evidence for saturable binding of ${ }^{125} \mathrm{I}$-insulin to the digestive epithelium of the entire digestive tract, from stomach to colon [12]. Using dispersed cells from the jejuno ileal rat mucosa, Forgue-Lafitte et al. demonstrated high affinity, specific and saturable binding sites for ${ }^{125}$ I-insulin [13].

Comparison of $\mathrm{RCI}$ in various segments of the gastrointestinal tract suggests that insulin receptors are more abundant in the proximal small bowel and least abundant in the colon. A similar conclusion could be reached after examination of Table 4, in which the highest surface density of silver grains is shown in the proximal small bowel epithelium and the lowest in that of the colon. Although this interpretation may be true, other explanations are possible. Indeed, following an intravenous injection into a live rat fetus, the amount of tracer extracted by any organ will depend not only upon its concentration of specific receptors, but also upon the local blood flow and the rapidity of ${ }^{125}$ I-insulin diffusion from the capillary lumen to the target cell membranes. Whatever the mechanism, either uneven receptor distribution or local differences in availability of plasma insulin, the observation remains that, in vivo, all segments of the gastrointestinal tract bind differing amounts of insulin.

Even 1 day before term, the digestive epithelium of the near-term fetus is immature and the glandular system is poorly developed. However, from the stomach to the colon, all epithelial cells, whether immature or already differentiated into mucus-producing or absorptive, appear to possess insulin receptors. Actually, rather than being associated with an individual cell type, the density of silver grains decreased from the basement membrane to the epithelium surface, no grains being associated with the luminal aspect of any cell. This distribution is consistent with diffusion of insulin from the capillaries to the basal layers of the epithelium and the lateral aspects of the surface epithelial cells and with prevention of further insulin diffusion into the lumen and luminal aspect of the surface epithelial cells by the tight junctions. In their description of insulin receptor distribution in the digestive tract of adult rats, Bergeron et al. also noted a pattern related to insulin diffusion rather than to cell type [12]. Thus, it appears that most entoblast-derived cells are equipped with insulin receptors including fetal bronchi [11, 14], gastrointestinal tract [12, 13], liver [5-7], gall-bladder [15] and exocrine pancreas [16].

It is interesting to note that the surface density of silver grains associated with the epithelium of the jejunoileum remained constant during the last 5 days of intrauterine life, despite cyto-differentiation and large changes of plasma insulin concentration, which rose from $130 \mathrm{mU} / 1$ on day 17 to $500 \mathrm{mU} / 1$ on day 20 and then fell to $90 \mathrm{mU} / 1$ on day 22 at delivery $[9,17]$.

At the present time, it is unknown which are the main effects exerted by insulin on the gastrointestinal tract, a well recognized target for other hormones. For instance, cortisol and thyroid hormones have been demonstrated to induce and regulate intestinal brush border enzymes [18-20]. A similar effect of insulin has been reported by Menard and Malo for the appearance of intestinal sucrase activity [21] and more recently by the same authors, for precocious induction of other disaccharidases and peptidases [22]. However, the wide distribution of insulin receptors among all gastrointestinal tract epithelial cells suggests that insulin also exerts more fundamental effects, such as cell growth and multiplication, to compensate for shedding. In this respect, it is interesting to note that insulin has been shown recently to stimulate the growth of a cell line derived from a human colonic cancer [23] and to increase ${ }^{3} \mathrm{H}$-thymidine incorporation into the digestive epithelium of normal mice [24]. 
Clearly, this and previous reports point to the digestive tract as a yet unrecognized major component of the plasma insulin clearing system and as a potentially important target of insulin.

Acknoledgment. This work was supported by grants from the National Fund for Scientific Research, Brussels, Belgium. The authors are indebted to M. Fodor for secretarial assistance.

\section{References}

1. Sodoyez-Goffaux F, Sodoyez JC, De Vos CJ (1977) Transient diabetes mellitus in a neonate. J Pediatr 91 : 395-399

2. Gentz JCH, Cornblath M (1969) Transient diabetes of the newborn. Adv Pediatr 16: 345-363

3. Susa JB, McCormick KL, Widness JA, Singer DB, Oh W, Adamsons K, Schwartz R (1979) Chronic hyperinsulinemia in the fetal rhesus monkey. Effects on fetal growth and composition. Diabetes 28: 1058-1063

4. Posner BI (1974) Insulin receptors in human and animal placental tissue. Diabetes 23: 209-217

5. Sodoyez-Goffaux F, Sodoyez JC, De Vos CJ (1982) Maturation of liver handling of insulin in the rat fetus. Diabetes 31:60-69

6. Vinicor F, Keidiowski L (1982) Characterization of the hepatic receptor for insulin in the perinatal rat. Endocrinology 110: 782-790

7. Neufeld ND, Scott M, Kaplan SA (1980) Ontogeny of the mammalian insulin receptor. Studies of human and rat fetal liver plasma membranes. Develop Biol 78: 151-160

8. Santora AC, Wheeler FB, De Haan RL, Elsas LJ (1979) Relationship of insulin binding to aminoacid transport by cultured 14-day embryonic chick heart cells. Endocrinology 104: 1059-1068

9. Sodoyez-Goffaux F, Sodoyez JC, De Vos CJ (1979) Insulin secretion and metabolism during the perinatal period in the rat. Evidence for a placental role in fetal hyperinsulinemia. J Clin Invest 63: 1095-1102

10. Sodoyez JC, Sodoyez-Goffaux F, Goff MM, Zimmerman AE, Arquilla ER (1975) $\left[{ }^{127} I\right]$ or carrier-free $\left[{ }^{125} \mathrm{I}\right]$ monoiodoinsulin. Preparation, physical, immunological and biological properties and susceptibiltiy to "insulinase" degradation. J Biol Chem 250: $4268-4277$

11. Sodoyez-Goffaux F, Sodoyez JC, De Vos CJ (1981) Insulin receptors in the fetal rat lung. A transient characteristic of fetal cells? Pediatr Res 15: 1303-1307

12. Bergeron JJM, Rachubinski R, Searle N, Borts D, Sikstrom R, Posner BI (1980) Polypeptide hormone receptors in vivo: demonstration of insulin binding to adrenal gland and gastrointestinal epithelium by quantitative radioautography. J Histochem Cytochem 28: 824-835

13. Forgue-Lafitte ME, Marescot MR, Chamblier MC, Rosselin G
(1980) Evidence for the presence of insulin binding sites in isolated rat intestinal epithelial cells. Diabetologia 19: 373-378

14. Devaskar SU, Ganguli S, Devaskar UP, Sperling MA (1982) Glucocorticoids and hypothyroidism modulate development of fetal lung insulin receptors. Am J Physiol 242: E384-391

15. Kobari L, Forgue-Lafitte ME, Chamblier MC, Rosselin G (1981) Insulin receptors in human gallbladder epithelial cells. Diabetologia 21: 292 (Abstract)

16. Bergeron JJM, Rachubinski R, Searle N, Sikstrom R, Borts D, Bastian P, Posner BI (1980) Radioautographic visualization of in vivo insulin binding to the exocrine pancreas. Endocrinology 107: 1069-1080

17. Felix JM, Sutter MT, Sutter BChJ, Jacquot R (1971) Circulating insulin and tissular reactivity to insulin in the rat during the perinatal period. Horm Metab Res 3: 71-75

18. Moog F (1953) The functional differentiation of the small intestine III. Influence of the pituitary adrenal system on the differentiation of phosphatase in the duodenum of the suckling mouse. J Exp Zool 124: 329-346

19. Yeh KY, Moog F (1974) Intestinal lactase activity in the suckling rat: influence of hypophysectomy and thyroidectomy. Science 182: 77-79

20. Yeh KY, Moog F (1977) Influence of the thyroid and adrenal glands on the growth of the intestine of the suckling rat and on the development of intestinal alkaline phosphatase and disaccharidase activities. J Exp Zool 200: 337-348

21. Menard D, Malo C (1979) Insulin-evoked precocious appearance of intestinal sucrase activity in suckling mice. Develop Biol 69: $661-665$

22. Menard D, Malo C, Calvert R (1981) Insulin accelerates the development of intestinal brush border hydrolytic activities of suckling mice. Develop Biol 85: 150-155

23. Cezard JP, Forgue-Lafitte ME, Chamblier MC, Rosselin G (1981) Growth promoting effect, biological activity and binding of insulin in human cancer cells in culture. Cancer Res 41: 1148-1153

24. Scheving LA, Scheving LE, Tsai TH, Pauly JE (1982) Circadian stage-dependent effects of insulin and glucagon on incorporation of ${ }^{3} \mathrm{H}$ thymidine into desoxyribonucleic acid in the esophagus, stomach, duodenum, jejunum, ileum, caecum, colon, rectum and spleen of the adult female mouse. Endocrinology 111:308-315

Received: 12 December 1983

and in revised form: 1 October 1984

Dr. F. Sodoyez-Goffaux

Department of Paediatrics

University of Liège

Hôpital de Bavière

66 Boulevard de la Constitution

B-4020 Liège

Belgium 